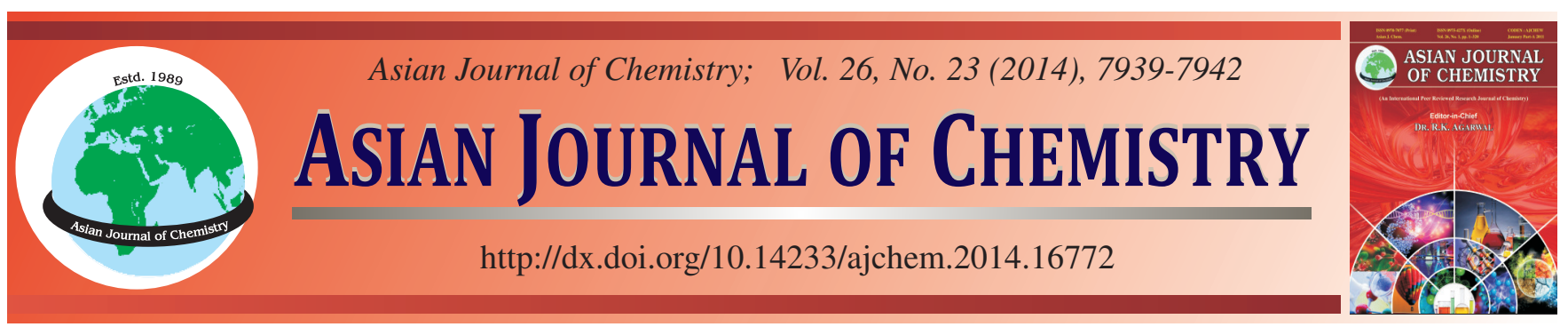

\title{
Discharge Behavior of Tungsten(VI) Oxide Cathodes in Medium-Temperature Lithium Batteries for Borehole Applications
}

\author{
Z.J. WANG ${ }^{1,2}$, J.L. Du ${ }^{1,2}$ Z.L. $\operatorname{Li}^{1}$ and Z. Wu ${ }^{1, *}$
}

${ }^{1}$ Research center for new energy technology, Shanghai Institute of Microsystem and Information Technology, Chinese Academy of Sciences, Shanghai, P.R. China

${ }^{2}$ University of Chinese Academy of Sciences, Beijing, P.R. China

*Corresponding author: Fax: +86 21 32200534; Tel: +86 21 69976918; E-mail: wuzhu@mail.sim.ac.cn

Received: 27 November 2013; $\quad$ Accepted: 12 January 2014; $\quad$ Published online: 15 November 2014; $\quad$ AJC-16268

\begin{abstract}
We have investigated the electrochemical properties of $\mathrm{WO}_{3}$ and $\mathrm{Li}_{2} \mathrm{WO}_{4}$ used as cathode materials for medium-temperature $\left(200-300{ }^{\circ} \mathrm{C}\right)$ lithium batteries coupled with binary and ternary nitrate eutectic electrolytes. Discharge tests are performed on the combinations of $\mathrm{LiMgB} /$ nitrate/tungsten (VI) oxide cells at a current density of $10 \mathrm{~mA} \cdot \mathrm{cm}^{-2}$. In general, compared with $\mathrm{Li}_{2} \mathrm{WO}_{4}$ cathode, $\mathrm{WO}_{3}$ presents multistep and more sloping voltage plateaux and much less capacities. Compared with binary $\mathrm{LiNO}_{3}-\mathrm{KNO}_{3}$ electrolyte, ternary $\mathrm{LiNO}{ }_{3}-$ $\mathrm{KNO}_{3}-\mathrm{CsNO}_{3}$ electrolyte shows better kinetic activity. The highest cathode capacity of $397.09 \mathrm{mAh} \mathrm{g}^{-1}$ to a $1 \mathrm{~V}$ cut-off appears in the $\mathrm{LiMgB} / \mathrm{LiNO}_{3}-\mathrm{KNO}_{3} / \mathrm{Li}_{2} \mathrm{WO}_{4}$ cell at $200{ }^{\circ} \mathrm{C}$. The compatibility research between tungsten (VI) oxides and nitrate eutectics indicates that no obvious exothermic reactions occur in the temperature range envisaged. The specific reaction mechanisms of the $\mathrm{WO}_{3}$ and $\mathrm{Li}_{2} \mathrm{WO}_{4}$ cathodes are also preliminarily investigated by XRD method.
\end{abstract}

Keywords: Tungsten (VI) oxide cathodes, Medium-temperature lithium batteries, Discharge behavior, Borehole applications.

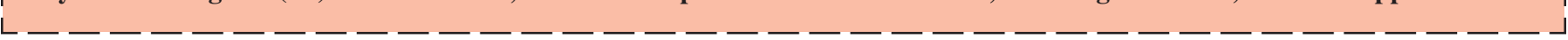

\section{INTRODUCTION}

Modified lithium/thionyl chloride batteries are widely used as power supplies for measurement while drilling (MWD) equipment in boreholes for geothermal, oil and gas exploration ${ }^{1}$. This energy supply system usually works with characteristics of low current, long life and a wide operating temperature range. However, due to the low decomposition temperature of $\mathrm{SOCl}_{2}$ and high vapor pressure inside batteries at higher temperatures, this technology is strictly limited below $200^{\circ} \mathrm{C}$. The use of dewars above $200^{\circ} \mathrm{C}$ expands the operating temperature range but also increases the cost of production simultaneously. So much attention has been paid to develop a new battery technology using low-temperature molten salt electrolytes in recent years ${ }^{2}$. After extensive material screening tests, nitrate-transition metal oxide combinations have been found to well meet the demand of practical work. The nitrate eutectics with relatively low melting points melt automatically by the use of the heat of boreholes, which can eliminate additional internal pyrotechnic and simplify cell structures tremendously. Also, a number of transition metal oxide cathodes are compatible with nitrates without any exothermic reaction between them in the operating temperature range, which are quite superior to the traditional sulphur-based cathodes in thermal batteries. The basic electrochemistry of nitrate-containing molten salt electrolytes and transition metal oxide cathodes has been widely studied by Miles ${ }^{3-5}$. Guidotti et al. ${ }^{6,7}$ have reported the discharge behavior and applicability of the $\mathrm{Ag}_{2} \mathrm{CrO}_{4}$ and $\mathrm{MnO}_{2}$ cathodes. These systems all show excellent performances in the envisaged work environment for boreholes.

$\mathrm{WO}_{3}$ was used primarily as a cathode material in thermal batteries in the early 1950 s coupled with $\mathrm{Ca}$ or $\mathrm{Mg}$ anodes ${ }^{8}$, but due to its poor conductivity and reactivity with halide melts, this technology was quickly replaced by the $\mathrm{Ca} / \mathrm{CaCrO}{ }_{4}$ system in the mid-1950s. In addition, there is almost no information in the open literature concerning the electrochemistry of the $\mathrm{WO}_{3}$ as used in thermal batteries ${ }^{9,10}$. However, for the mediumtemperature lithium batteries, nitrates rather than halides are used as electrolytes. Graphite can be added to improve the electrical conductivity effectively, so $\mathrm{WO}_{3}$ is worth being reevaluating the feasibility as a cathode material in mediumtemperature batteries. As is known that transition metal oxides generally have the disadvantages of low electrical conductivity and poor thermal stability. However, lithiation of them can produce both thermally stable and electronically conducting structures which will accept additional lithium ions during the reduction ${ }^{11}$. Here, we take tungsten (VI) oxide and lithiated tungsten (VI) oxide as our objects of study. Discharge behavior, reaction mechanism and compatibility with binary and ternary 
nitrate salts will be discussed in detail. The ultimate goal is to study the electrochemistry of $\mathrm{WO}_{3}$ and $\mathrm{Li}_{2} \mathrm{WO}_{4}$ and develop a proper medium-temperature lithium battery system.

\section{EXPERIMENTAL}

$\mathrm{WO}_{3}$ and $\mathrm{Li}_{2} \mathrm{WO}_{4}$ from Strem Chemical Inc. and other starting materials from Sinopharm Chemical Reagent Co, Ltd were all of reagent grade with purity higher than $98.5 \%$. (Unless otherwise noted, all compositions are reported as weight percent). The LiMgB alloy anode (64 \% Li, $4 \% \mathrm{Mg}$ and $32 \%$ B) was prepared by ourselves. Anodes were obtained by punching disks (15.5 mm diameter, $0.09 \mathrm{~g}$ mass) from $\mathrm{LiMgB}$ foil (0.44 mm thickness). All salts were vacuum-dried at $100{ }^{\circ} \mathrm{C}$ overnight before use. The eutectic ratios of the $\mathrm{LiNO}_{3}-\mathrm{KNO}_{3}$ electrolyte $\left(33.2 \% \mathrm{LiNO}_{3}, 66.8 \% \mathrm{KNO}_{3}\right)$ and $\mathrm{LiNO}_{3}-\mathrm{KNO}_{3}$ $\mathrm{CsNO}_{3}$ electrolyte $\left(21.43 \% \mathrm{LiNO}_{3}, 35.54 \% \mathrm{KNO}_{3}\right.$ and $43.03 \% \mathrm{CsNO}_{3}$ ) were both weighed out and fused for $16 \mathrm{~h}$ at $300{ }^{\circ} \mathrm{C}$. The catholytes were prepared by blending $70 \% \mathrm{WO}_{3}$ or $\mathrm{Li}_{2} \mathrm{WO}_{4}$ with $20 \%$ electrolyte and $10 \%$ graphite, electrolyte and graphite were added necessarily to improve the ionic and electrical conductivity respectively. Then the mixture was vacuum-dried at $80^{\circ} \mathrm{C}$ for $8 \mathrm{~h}$ to eliminate extra moisture.

Analysis of materials: To determine the compatibility between tungsten (VI) oxides and nitrate eutectics, simultaneous TGA/DSC was performed on a NETZSCH STA 449F3 thermal analyzer. The thermal analysis samples were sealed in an $\mathrm{Al}_{2} \mathrm{O}_{3}$ pan, the heating rate was $5^{\circ} \mathrm{C} / \mathrm{min}$ and the upper limit temperature was set as $350{ }^{\circ} \mathrm{C}$. To identify reaction mechanisms of the two cathodes, XRD was performed on a Rigaku D/MAX-2200/PC diffractometer with $\mathrm{CuK}_{\alpha}$ radiation, the scanning range was from $10^{\circ}$ to $90^{\circ}$ with a scanning speed of $4 \% \mathrm{~min}$.

Preparation of pellets for single cell tests: Experimental single cells consisted of a $0.09 \mathrm{~g} \mathrm{LiMgB}$ pellet and a bilayer pellet consisting of $0.50 \mathrm{~g}$ each of depolarizer-electrolyte (DE) and electrolyte binder (EB) layers pressed at $222 \mathrm{MPa}$. Then the two pellets were sandwiched between stainless steel current collectors and put between heated plates in a glovebox under an atmosphere of high-purity argon $(<1 \mathrm{ppm}$ each of water and oxygen). Mica insulations were used between single cells and heated plates to avoid any electrical contact. The discharge measurements were performed on an EG\&G PARC Model 273A potentiostat/galvanostat controlled with the Model 270 software package in a temperature range of $200-300{ }^{\circ} \mathrm{C}$. A steady-load of $18.9 \mathrm{~mA}\left(10 \mathrm{~mA} \mathrm{~cm}{ }^{-2}\right)$ was used, which was adequate for the envisioned application ${ }^{6}$. The discharge process was terminated when the voltage dropped below $1 \mathrm{~V}$.

\section{RESULTS AND DISCUSSION}

Thermal analyses: Thermal analysis was accomplished prior to high-temperature discharge tests to avoid any risks, especially runaway in batteries. Any cell combination containing intense exothermic reactions in the predetermined temperature range should be eliminated. The compatibility between two kinds of active cathodes and two kinds of nitrate eutectics was examined by TG/DSC analyses. The results are shown in Figs. 1a, b.
It can be seen from Fig. 1a that the four TG curves only present different levels of decline slightly, which most likely corresponds to the removing of moisture in the samples. As shown in Fig. 1b, there is only two endothermic peaks appear in DSC curves for the binary eutectic below $300{ }^{\circ} \mathrm{C}$ without any exothermic peak. The main peak at $135.1^{\circ} \mathrm{C}$ is agreement with the melting point of the $\mathrm{LiNO}_{3}-\mathrm{KNO}_{3}$ eutectic (124.5 ${ }^{\circ} \mathrm{C}$ ) but a little higher. The other weaker peak at 123.3 or 121.5 ${ }^{\circ} \mathrm{C}$ may result from the impurities in starting materials. With the increasing of temperature, fluctuation of curve begins to appear from $314.1^{\circ} \mathrm{C}$ in the $\mathrm{LiNO}_{3}-\mathrm{KNO}_{3} / \mathrm{WO}_{3}$ cell. However, there is no corresponding evidence in the TG curve of this combination as to exothermic reactions occur in this temperature range. The results associated with the ternary $\mathrm{LiNO}_{3}$ $\mathrm{KNO}_{3}-\mathrm{CsNO}_{3}$ eutectic show that only a single endothermic peak appeared at $122{ }^{\circ} \mathrm{C}$ or $120.6{ }^{\circ} \mathrm{C}$ in DSC curses which corresponds to the melting point of the ternary eutectic $(96 \pm$ $\left.2{ }^{\circ} \mathrm{C}\right)^{12}$ but a little higher. TG curves also well ensure the safety of these two cell combinations below $350{ }^{\circ} \mathrm{C}$.
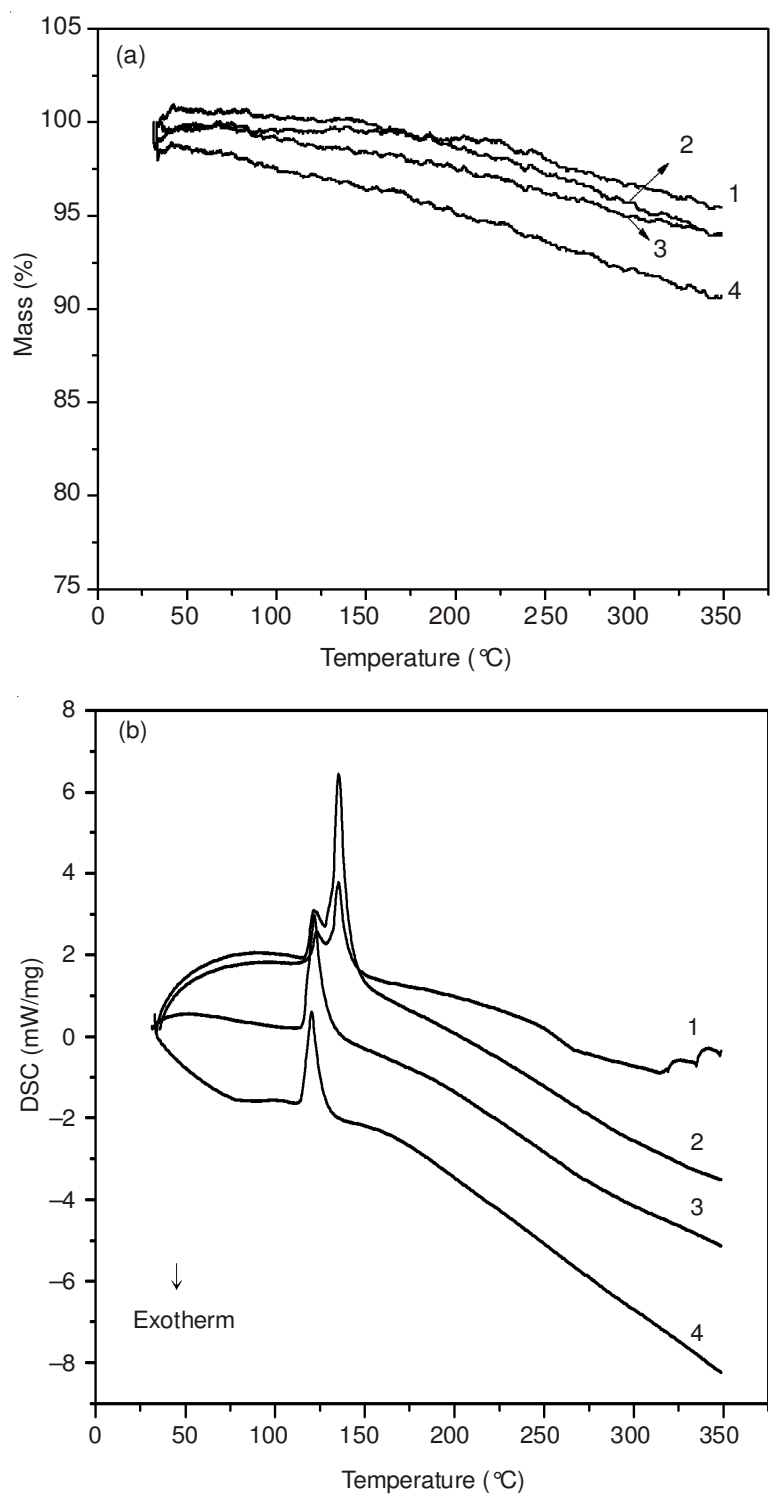

Fig. 1. TG and DSC curves of (1) $\mathrm{WO}_{3}+$ binary eutectic, (2) $\mathrm{Li}_{2} \mathrm{WO}_{4}+$ binary eutectic, (3) $\mathrm{WO}_{3}+$ ternary eutectic, (4) $\mathrm{Li}_{2} \mathrm{WO}_{4}+$ ternary eutectic 
Single cell tests: The discharge curves obtained for $\mathrm{WO}_{3}$ and $\mathrm{Li}_{2} \mathrm{WO}_{4}$ are presented in Figs. 2a and 2b, respectively at 200 and $300^{\circ} \mathrm{C}$ coupled with the two eutectic electrolytes. As is shown in Figs. 2a and Table-1, the $\mathrm{LiMgB} / \mathrm{WO}_{3}$ cells each has an open-circuit voltage (OCV) of around 3.4 V. At a higher temperature of $300{ }^{\circ} \mathrm{C}$, higher and more distinct voltage plateaux and much higher capacities are the major differences from the corresponding results at $200^{\circ} \mathrm{C}$. These improvements may attribute to the higher reaction activity of the $\mathrm{WO}_{3}$ cathode at $30{ }^{\circ} \mathrm{C}$. The two distinct voltage plateaux at $300^{\circ} \mathrm{C}$ indicate a two-step redox reaction during discharge together with lithium intercalation. At each temperature, cells with ternary eutectic electrolyte usually perform better on the aspects of voltage plateau and discharge capacity than those with binary eutectic electrolyte. As the melting point of ternary $\mathrm{LiNO}_{3}$ $\mathrm{KNO}_{3}-\mathrm{CsNO}_{3}$ eutectic is lower than that of the $\mathrm{LiNO}_{3}-\mathrm{KNO}_{3}$ eutectic, so higher kinetics is obtained in the ternary eutectic at the same temperature, which contributes to better electrochemical performance.

As is shown in Fig. 2b, only one distinct voltage plateau are presented in each $\mathrm{LiMgB} / \mathrm{Li}_{2} \mathrm{WO}_{4}$ cell, which indicates that $\mathrm{Li}_{2} \mathrm{WO}_{4}$ goes through a one-step redox reaction. These cells have wider and steadier voltage plateaux and much higher capacities than those of the $\mathrm{LiMgB} / \mathrm{WO}_{3}$ cells. The highest cathode capacity of $397.09 \mathrm{mAh} \mathrm{g}^{-1}$ appears in the LiMgB/ $\mathrm{LiNO}_{3}-\mathrm{KNO}_{3} / \mathrm{Li}_{2} \mathrm{WO}_{4}$ cell at $200{ }^{\circ} \mathrm{C}$. Rather than $\mathrm{WO}_{3}$, more simple lithium intercalation process occurs in $\mathrm{Li}_{2} \mathrm{WO}_{4}$ during discharge, which results to steadier plateaux. Frequent phase transitions resulting from multistep lithium intercalation occurred in $\mathrm{WO}_{3}$ and other Li-free transition metal oxides affect the structural stability and then the electrochemical performance. Unlike the $\mathrm{LiMgB} / \mathrm{WO}_{3}$ cells, better properties are obtained at the lower temperature of $200{ }^{\circ} \mathrm{C}$ rather than $300{ }^{\circ} \mathrm{C}$ for the $\mathrm{LiMgB} / \mathrm{Li}_{2} \mathrm{WO}_{4}$ cells. The increased self discharge in these cells at higher temperature is most likely responsible for it, which is similar with the $\mathrm{Li}(\mathrm{Al}) / \mathrm{MnO}_{2}$ cells? .

Phase structures analyses: As described earlier, the $\mathrm{WO}_{3}$ cathode experiences a distinct two-step reaction process at $300{ }^{\circ} \mathrm{C}$ and a one-step reaction occurs in the $\mathrm{Li}_{2} \mathrm{WO}_{4}$ cathode at both 200 and $300{ }^{\circ} \mathrm{C}$. XRD is used to detect the reaction products of $\mathrm{WO}_{3}$ and $\mathrm{Li}_{2} \mathrm{WO}_{4}$ and then analyze the specific mechanisms of them. The partially discharged cathode layers are stripped from the $\mathrm{LiMgB} / \mathrm{LiNO} \mathrm{LNO}_{3}-\mathrm{KNSNO}_{3} / \mathrm{WO}_{3}$ cell at $300{ }^{\circ} \mathrm{C}$ and the $\mathrm{LiMgB} / \mathrm{LiNO}_{3}-\mathrm{KNO}_{3} / \mathrm{Li}_{2} \mathrm{WO}_{4}$ cell at $200^{\circ} \mathrm{C}$, respectively which have the highest capacities for each of the cathodes. XRD patterns of the partially discharged cathode layers are shown in Fig. 3.
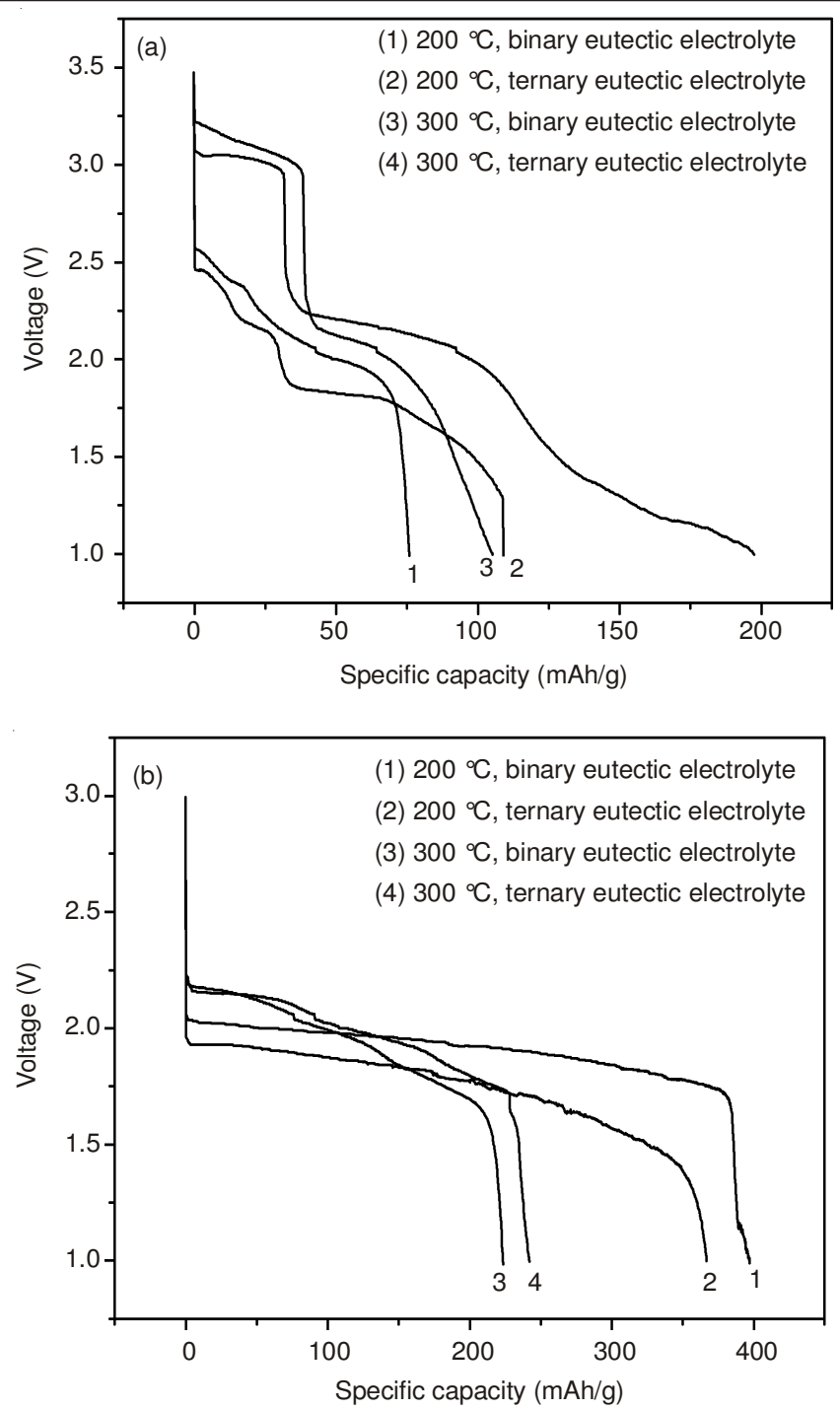

Fig. 2. Galvanostatic discharge profiles of (a) the $\mathrm{LiMgB} / \mathrm{WO}_{3}$ cells and (b) the $\mathrm{LiMgB} / \mathrm{Li}_{2} \mathrm{WO}_{4}$ cells

When the $\mathrm{WO}_{3}$ cathode is discharged to the end of the first voltage plateau, namely a $2.75 \mathrm{~V}$ cut-off, besides the diffraction peaks of additives, the others are well in agreement with the JCPDS cards of $7 \mathrm{Li}_{2} \mathrm{WO}_{4} \cdot 4 \mathrm{H}_{2} \mathrm{O}$ and $\mathrm{WO}_{3}$. The crystal water most likely comes from moisture in surroundings during the testing process. And the existence of $\mathrm{WO}_{3}$ indicates that not all the $\mathrm{WO}_{3}$ is involved in the process of lithium intercalation reaction. Similar to the products of the first plateau, the diffraction peaks are in accordance with JCPDS cards of $\mathrm{Li}_{2} \mathrm{WO}_{4}$ and $\mathrm{WO}_{3}$ for the $\mathrm{WO}_{3}$ cathode discharged to a $1 \mathrm{~V}$

TABLE-1

GALVANOSTATIC DISCHARGE RESULTS FOR THE $\mathrm{WO}_{3}$ AND $\mathrm{Li}_{2} \mathrm{WO}_{4}$ CATHODES

\begin{tabular}{ccccc}
\hline Cell combination & Temperature $\left({ }^{\circ} \mathrm{C}\right)$ & OCV $(\mathrm{V})$ & $\begin{array}{c}\text { Capacity to a 1V cut-off } \\
(\mathrm{mAh})\end{array}$ & $\begin{array}{c}\text { Energy density to a 1Vcut-off } \\
\left(\mathrm{mAh} \mathrm{g}^{-1}\right) \text { cathode }\end{array}$ \\
\hline \multirow{2}{*}{$\mathrm{LiNO}_{3}-\mathrm{KNO}_{3} / \mathrm{WO}_{3}$} & 200 & 3.411 & 27.18 & 77.66 \\
\hline \multirow{2}{*}{$\mathrm{LiNO}_{3}-\mathrm{KNO}_{3} / \mathrm{Li}_{2} \mathrm{WO}_{4}$} & 300 & 3.474 & 37.33 & 106.66 \\
\hline \multirow{2}{*}{$\mathrm{LiNO}_{3}-\mathrm{KNO}_{3}-\mathrm{CsNO}_{3} / \mathrm{WO}_{3}$} & 200 & 2.940 & 138.98 & 397.09 \\
\hline \multirow{2}{*}{$\mathrm{LiNO}_{3}-\mathrm{KNO}_{3}-\mathrm{CsNO}_{3} / \mathrm{Li}_{2} \mathrm{WO}_{4}$} & 300 & 2.679 & 80.59 & 230.26 \\
\hline
\end{tabular}




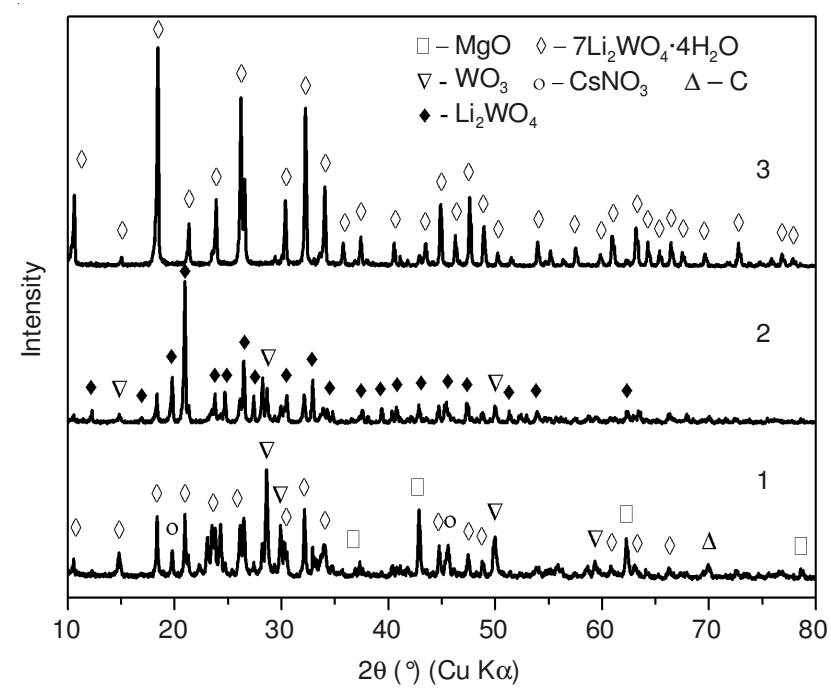

Fig. 3. X-ray diffractograms of the partially discharged cathode layers: (1) discharged $\mathrm{WO}_{3}$ to a $2.75 \mathrm{~V}$ cut-off; (2) discharged $\mathrm{WO}_{3}$ to a $1 \mathrm{~V}$ cut-off; (3) discharged $\mathrm{Li}_{2} \mathrm{WO}_{4}$ to a $1 \mathrm{~V}$ cut-off

cut-off. As the discharge process of $\mathrm{WO}_{3}$ is together with lithium intercalation and lithium-poor and lithium-rich lithium tungstates share the similar XRD patterns, we conclude that $\mathrm{WO}_{3}$ experiences a step-by-step lithium intercalation process on the two voltage plateaux and converts to $\mathrm{Li}_{\mathrm{x}} \mathrm{WO}_{4}$ (the $\mathrm{x}$ value increases with the decrease of the voltage plateaux), as shown in eqn. 1 . The increased oxygen is believed from the reduction of the $\mathrm{NO}_{3}^{-}$, which is reduced to $\mathrm{NO}_{2}$ and $\mathrm{O}^{2-}$ with the formation of the $\mathrm{Li}_{2} \mathrm{O}$ passivation film ${ }^{3}$, so the complete reaction can be rewritten as eqn 2 . The corresponding capacities of the two voltage plateaux are 31.89 and $167.57 \mathrm{mAh} \mathrm{g}^{-1}$, respectively, which equal to $\mathrm{Li}_{0.78} \mathrm{WO}_{4}$ and $\mathrm{Li}_{2.23} \mathrm{WO}_{4}$ are obtained at the end of the two plateaux, respectively if all the $\mathrm{WO}_{3}$ takes part in the reactions. However, the existence of unreacted $\mathrm{WO}_{3}$ in the two discharged samples proves that the actual values are higher than 0.78 and 2.23. In addition, in view of the limited reaction efficiency, the theoretical values in these equations are also higher than 0.78 and 2.23 respectively.

$$
\begin{gathered}
\mathrm{WO}_{3}+\mathrm{xLi}^{+}+\mathrm{e}^{-} \longrightarrow \mathrm{Li}_{\mathrm{x}} \mathrm{WO}_{4} \\
2 \mathrm{WO}_{3}+3 \mathrm{NO}_{3}^{-}+(2 \mathrm{x}+2) \mathrm{Li}^{+}+(2 \mathrm{x}-1) \mathrm{e}^{-} \longrightarrow \\
2 \mathrm{Li}_{\mathrm{x}} \mathrm{WO}_{4}+3 \mathrm{NO}_{2}+\mathrm{Li}_{2} \mathrm{O}
\end{gathered}
$$

For the discharged $\mathrm{Li}_{2} \mathrm{WO}_{4}$ samples, there is almost a oneto-one correlation between all the diffraction peaks and the JCPDS card of $7 \mathrm{Li}_{2} \mathrm{WO}_{4} \cdot 4 \mathrm{H}_{2} \mathrm{O}$. As per the above-mentioned analysis, it is believed that $\mathrm{Li}_{2} \mathrm{WO}_{4}$ converts to $\mathrm{Li}_{2+\mathrm{x}} \mathrm{WO}_{4}$ through a one-step lithium intercalation during discharge, as shown in eqn 3. It is calculated that the $\mathrm{x}$ value in $\mathrm{Li}_{2+\mathrm{x}} \mathrm{WO}_{4}$ is 3.88 according to the actual discharge capacity of $397.09 \mathrm{mAh}$ $\mathrm{g}^{-1}$. The higher amount of lithium intercalated in $\mathrm{Li}_{2} \mathrm{WO}_{4}$ than $\mathrm{WO}_{3}$ implies higher capacity of the $\mathrm{Li}_{2} \mathrm{WO}_{4}$ cathode.

$$
\mathrm{Li}_{2} \mathrm{WO}_{4}+\mathrm{xLi}^{+}+\mathrm{e}^{-} \rightarrow \mathrm{Li}_{2+\mathrm{x}} \mathrm{WO}_{4}
$$

\section{Conclusion}

The earlier cathode material for thermal batteries $-\mathrm{WO}_{3}$ and its lithiated oxide $\mathrm{Li}_{2} \mathrm{WO}_{4}$ are re-evaluated and investigated as cathode materials for medium-temperature $\left(200-300{ }^{\circ} \mathrm{C}\right)$ lithium batteries coupled with $\mathrm{LiNO}_{3}-\mathrm{KNO}_{3}$ and $\mathrm{LiNO}_{3}-\mathrm{KNO}_{3}-$ $\mathrm{CsNO}_{3}$ eutectics. The ternary electrolyte usually presents better electrochemical performance due to its lower melting point which brings better kinetics than binary electrolyte. Without frequent phase transitions which results to the increase of cell polarization, $\mathrm{Li}_{2} \mathrm{WO}_{4}$ presents much wider voltage plateaux and much higher capacities. It is believed that $\mathrm{WO}_{3}$ and $\mathrm{Li}_{2} \mathrm{WO}_{4}$ both convert to lithium insertion $\mathrm{LixWO}_{4}$ according to the XRD analysis. This preliminary study proves the better applicability of $\mathrm{Li}_{2} \mathrm{WO}_{4}$ in medium-temperature $\left(200-300{ }^{\circ} \mathrm{C}\right)$ lithium batteries and more detailed studies are in progress.

\section{ACKNOWLEDGEMENTS}

This work was financially supported by Hi-Tech Research and Development Program of China (2007AA05Z149) and the Scientific Research Project of Science and Technology Commission of Shanghai Municipality (09dz1206800).

\section{REFERENCES}

1. R.A. Guidotti, F.W. Reinhardt and J. Odinek, J. Power Sources, 136, 257 (2004)

2. R.A. Guidotti, In $35^{\text {th }}$ Intersociety Energy Conversion Engineering Conference and Exhibit, IEEE, USA, pp. 1276-1286 (2000).

3. M.H. Miles, In Proceedings of the $39^{\text {th }}$ Power Sources Conference, U.S. Army Research Laboratory, USA, pp. 560 (2000).

4. M.H. Miles, In International Symposium on Batteries and Supercapacitors, San Francisco, USA, pp. 557-563 (2001).

5. M.H. Miles, In Proceeding of the 1999 IEEE Battery Conference on Applications and Advances, IEEE, USA, pp. 39-42 (1999).

6. R.A. Guidotti and F.W. Reinhardt, In Proceedings of the $36^{\text {th }}$ Intersociety Energy Conversion Engineering Conference, USA, pp.31-42 (2001).

7. R.A. Guidotti and F.W. Reinhardt, In Proceedings of the $41^{\text {st }}$ Power Sources Conference, USA, pp. 141-144 (2004).

8. H. Goldsmith and J.T. Smith, J. Electrochem. Soc., 6, 16 (1968).

9. P.J. Masset and R.A. Guidotti, J. Power Sources, 178, 456 (2008).

10. R.A. Guidotti and P.J. Masset, J. Power Sources, 161, 1443 (2006).

11. M.E. Bolster and R.J. Stanlewicz, In Proceedings of the $34^{\text {th }}$ International Power Sources Symposium, IEEE, USA, pp. 136-140 (1990).

12. J. Wang and R.A. Huggins, J. Electrochem. Soc., 130, 310 (1983).

13. I.D. Raistrick, J. Poris and R.A. Huggins, In Proceedings of the Symposium on Lithium Batteries, USA, pp. 477-483 (1981). 